\title{
Grassland fire effects on corroded barbed wire
}

\author{
DAVID M. ENGLE AND JOHN R. WEIR
}

Authors are professor and station superintendent, Department of Plant and Soil Sciences, Oklahoma State University, Stillwater, Okla. 74078.

\begin{abstract}
Fire effects on rangeland ecosystems have been studied extensively. Few studies have investigated effects of fire on rangeland developments. Only 1 study has investigated the effects of fire on barbed wire with an intact coating of corrosion-resistant zinc and no studies have investigated wire that has lost the protective coating. A common perception is that grass fire causes older wire to break more easily and become more brittle. In the present study, we determined the influence of grassland fire on wire that was 20 and 30-years old and had sufficient loss of the zinc coating to have undergone corrosion of the underlying steel. We found that regardless of age, wire subjected to grass fire did not differ $(P>0.05)$ in breaking strength, elongation, or ductility from the same wire that was not subjected to fire. We conclude that the problems experienced when repairing breaks in old barbed wire are not a result of fire, but rather brittle and weak wire resulting from exposure to the corrosive elements of the environment.
\end{abstract}

Key Words: Fence, prairie fire, Oklahoma

The results of numerous studies are available from throughout the world on the response of rangeland ecosystems to fire. Fencing is a rangeland development with potential exposure to fire. However, little is known of fire effects on fencing except for influences on preservative-treated wood posts (e.g., McCarthy et al. 1972, Evans et al. 1994) and our recent research on the effects of grassland fire on barbed wire (Engle et al.1998). The effects of fire on barbed wire are important to rangeland managers because of the amount of wire exposed to wildfire and because the effects of fire on barbed wire are often viewed as a major limitation to implementing prescribed burning on rangelands.

Most rangeland fence is constructed of 2-point or 4-point, double-stranded, zinc-coated barbed wire that is labeled and marketed according to quality standards specified by the American Society for Testing and Materials (ASTM 1995). The American Society for Testing and Materials has published 12 and 20-year long-term studies of the effects of various environments and climates on barbed wire (Reinhart 1961, Kelly 1975), but has not investigated the effects of fire. Other than our recent research (Engle et al. 1998), no formal studies to our knowledge have been conducted to determine rangeland fire effects on barbed wire or other galvanized fencing materials commonly used on rangelands. Engle et al. (1998) determined that even 6 grass fires did

This research was supported by the Oklahoma Agricultural Experiment Station through project S-2044 and is approved for publication by the Director of the Oklahoma Agricultural Experiment Station. The authors thank Mike Murphy of Oklahoma Steel and Wire Co., Inc. in Madill, Oklahoma, USA, for testing wire for breaking strength and elongation.

Manuscript accepted 24 Jan. 2000.
Resumen

Los efectos del fuego en los ecosistemas de pastizal se han estudiado extensivamente, pero pocos estudios han investigado los efectos del fuego en la infraestructura del pastizal. Solo un estudio ha investigado el efecto del fuego en el alambre de $p$ as con una capa intacta de anticorrosivo a base de zinc, y no hay estudios que investiguen el efecto del fuego en alambre que ha perdido esta capa protectora. Una precepción com n es que el fuego causa que el alambre viejo se rompa mas f•cilmente y llegue a ser mas rágido. En el presente estudio determinamos la influencia del fuego en alambre de 20 y 30 años de edad que habáa perdido suficiente cubierta protectora de zinc para tener corrosión. Encontramos que independientemente de la edad, la resistencia a la ruptura, elongación y ductibilidad del alambre sujeto al fuego no difiere $(P>0.05)$ del alambre en igualdad de condiciones pero no sujeto a fuego. Concluimos que los problemas experimentados durante la reparación de rupturas de alambres viejos de $p$ as no son el resultado del fuego, sino mas bien, la rigidez y debilidad del alambre resultan de su exposición a los elementos corrosivos del ambiente.

not adversely affect the breaking strength or zinc coating of Class $1,121 / 2$ gauge barbed wire that still had a protective coating of zinc when first subjected to a grassland fire. This contradicted the common perception that grassland fire, either by reducing strength or by removing the corrosion-resistant zinc coating, reduces the life of galvanized barbed wire.

Another common perception is that grassland fire causes older wire to break more easily (i.e., looses tensile strength) and become more brittle (i.e., looses ductility). If so, wire would break more readily when stretched or when wrapped to splice a break. Hence, our objective in this study was to determine the influence of grassland fire on older wire that had sufficient loss of the zinc coating to have undergone corrosion of the underlying steel. Specifically, we determined the influence of grassland fire on breaking strength, elongation, and ductility of old, corroded wire in use in still serviceable barbed wire fence.

\section{Methods and Materials}

We collected 75-cm sections of 12 1/2-gauge, 2-point, doublestranded barbed wire from fence with minimum ages of 20 and 30 years and from newly manufactured, unused ASTM Class 1 wire. Used wire was collected in the spring and summer of 1997 in Payne County, Okla., USA, from fence constructed of new wire in 1968 and 1978. None of this wire had been subjected to fire before this study. Both the 20 and 30 -year-old wire displayed complete loss of the protective zinc layer, and extensive corrosion 
Table 1. Fine fuel loading and behavior of fires at three locations in tallgrass prairie to test effects on barbed wire. Values for fuel load are the mean (SE) of 10 samples. Values for fire intensity and heat per unit area were the observed behavior of 1 fire run at each location and were calculated from rate of spread estimated by 2 observers.

\begin{tabular}{lccc}
\hline \hline Location & Fuel load & Fire intensity & Heat per unit area \\
\hline & $\left(\mathrm{kg} \mathrm{ha}^{-1}\right)$ & $\left(\mathrm{kW} \mathrm{m}^{-1}\right)$ & $\left(\mathrm{kJ} \mathrm{m}^{-2}\right)$ \\
1 & $2,640(100)$ & 1,260 & 3,900 \\
2 & $4,920(600)$ & 2,370 & 7,340 \\
3 & $5,320(170)$ & 4,360 & 7,850 \\
\hline
\end{tabular}

of the steel was visible. Pitting of the 30year-old wire was visually observed to be deeper and more extensive than on the 20year-old-wire. Additional wire samples were obtained from newly manufactured unused rolls of ASTM Class 1 barbed wire.

A subset of the wire was subjected to fires located in tallgrass prairie fuels and burned 4 November 1997 in the early dormant season. Three sections of wire from each treatment (unused, 20-year old, and 30-year old) were attached, unstretched, with wire clips to steel T-posts at three topographically level locations in a 65-ha pasture within a tallgrass prairie $(n=9)$. Fine fuel load varied among locations as a result of differences in site potential and differential grazing by cattle (Table 1 ). Each section of wire was positioned $60 \mathrm{~cm}$ above the soil surface. This corresponds to the typical height of the second wire in a fence and within the zone of peak temperatures measured in previous fires in similar tallgrass prairie fuels at this same study location (Engle et al. 1989, Bidwell and Engle 1991). At each location, a headfire was ignited upwind about $5 \mathrm{~m}$ and allowed to spread into the area where the wire was positioned. Fuel loading and fire behavior (Table 1) were comparable to fires in tallgrass prairies burned at other dates (Engle et al. 1989, Engle et al. 1990, Bidwell and Engle 1992, Engle et al. 1993). A second subset of wire was used as a nonburned control $(n=6)$.

After the fires, the double-stranded wire was separated into single strands and the barbs removed. A $30-\mathrm{cm}$ subset $(n=6)$ of the single strands of wire was tested for breaking strength according to ASTM A 121-92a for zinc-coated (galvanized) steel barbed wire (ASTM 1995). Oklahoma Steel and Wire Co., Inc. of Madill, Okla, USA, conducted tests of breaking strength and permanent elongation. Elongation is the increase in length of the fractured wire specimen expressed as a percentage of the original length of the wire before subjecting it to the test for breaking strength. We used elongation as a surrogate for the wire to undergo stretching before breaking.
Elongation was tested according to ASTM A 370 A4.4 for round wire. A second set $(n=9)$ of the single strands of wire was subjected to the wrap test, a test for ductility, following the procedure outlined

in ASTM A 370 A4.7 (ASTM 1995). The test consists of coiling the wire in a closely spaced helix against a mandrel of 0.25 $\mathrm{cm}$ diameter. The wire was coiled a maximum of five times. Failure was considered as any longitudinal or transverse cracks detected by the unaided eye after the first complete turn.

Statistical comparisons of burned and nonburned samples within wire age (i.e., unused, 20-year old, and 30-year old) were made using Student's t-test. The null hypothesis was that breaking strength, elongation, and ductility of wire would not differ between wire subjected to grassland fire and wire not subjected to grassland fire within any of the age groups. Differences were considered significant at the 0.05 level.

\section{Results and Discussion}

Regardless of age, wire subjected to fire in tallgrass prairie did not differ in breaking strength, elongation, or ductility from wire that was not subjected to fire (Fig. 1, 2, and $3)$. Therefore, we failed to reject our hypothesis that breaking strength, elongation, and ductility of wire would not differ between wire subjected to grassland fire and wire that was not. As galvanized steel barbed wire rusts, it loses strength and ductility after the corrosion-protective zinc coating is lost in exposure to the natural environment (Reinhart 1961, Kelly 1975). The barbed wire we collected from existing fences exhibited complete failure of the protective zinc coating. Fire did not further reduce strength, elongation potential, or ductility in spite of the advanced corrosion of the 30-year-old wire.

A common perception among rangeland managers has been that fire, either by reducing strength or by removing the corrosion-resistant zinc coating, reduces the life of barbed wire. Our recently reported research showed that even repeated grass fires did not reduce the breaking strength or corrosion resistance of 14-year old Class 1, 12 1/2 gauge barbed wire (Engle et al. 1998). Results of the present study contradict another common perception that grassland fire causes older wire to break more easily and become more brittle. The weaker and more brittle the wire, the more readily the wire will break when stretched or wrapped to splice a break.

Our results have 2 implications to barbed wire fences with advanced corrosion. First, rangeland managers often assert that they find more broken wire after grass fires. If so, a number of factors may explain this increased incidence of broken wire. Perhaps wires are broken in

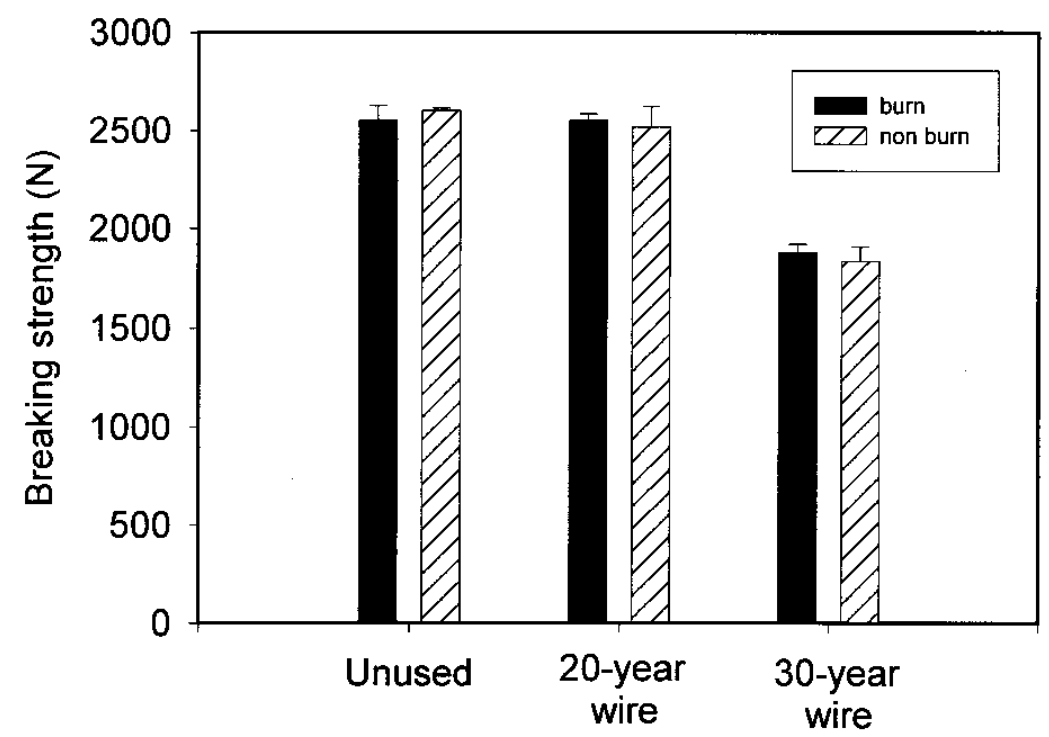

Fig. 1. Breaking strength in newtons $(\mathrm{N})$ of single strands of barbed wire subjected to grassland fire. Values are means of 9 observations (burn) and 6 observations (non burn); bars are 1 standard error. Burn treatments did not differ $(P>0.05)$ for wire of any age. 


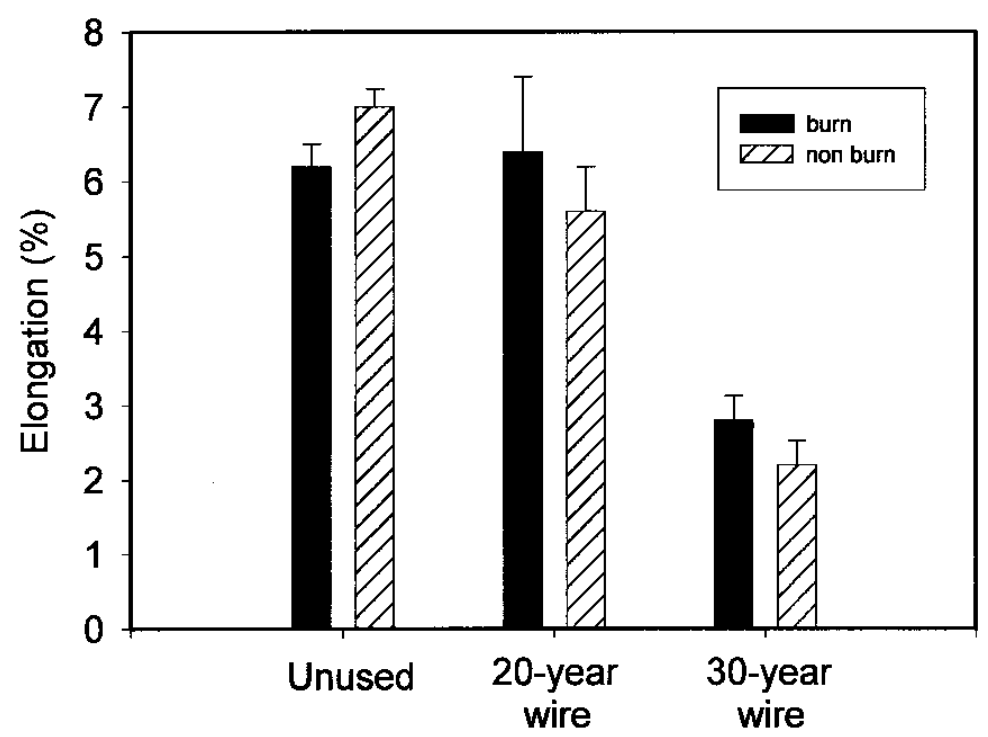

Fig. 2. Permanent elongation of single strands of barbed wire subjected to grassland fire. Values are means of 9 observations (burn) and 6 observations (non burn); bars are 1 standard error. Burn treatments did not differ $(P>0.05)$ for wire of any age.

some way in expansion and contraction during the fire, specifically at contact points such as at staples on wood posts that undergo accelerated wear from friction. Similar accelerated wear occurs at contact points for other reasons including expansion and contraction with changes in ambient air temperature. The effect of expansion and contraction on contact points could be tested under various stretching configurations, for example, across posts in curved or v-shaped configurations. We do not think placing wire under tension (i.e., stretching) would alter the results of our study because, in our

previous research (Engle et al. 1998), breaking strength of wire subjected to fire did not decrease because of stretching. In that research, we found no difference in breaking strength between stretched wire that was burned and unused wire that had never been stretched or burned.

Fire suppression or ignition activities may also be responsible for breaks in wire. We think the latter is especially probable during wildfire suppression when vehicles make unintended contact with fences. In some fuel types, already broken wires would be more easily seen after obstructing vegetation is removed in the fire. Finally,

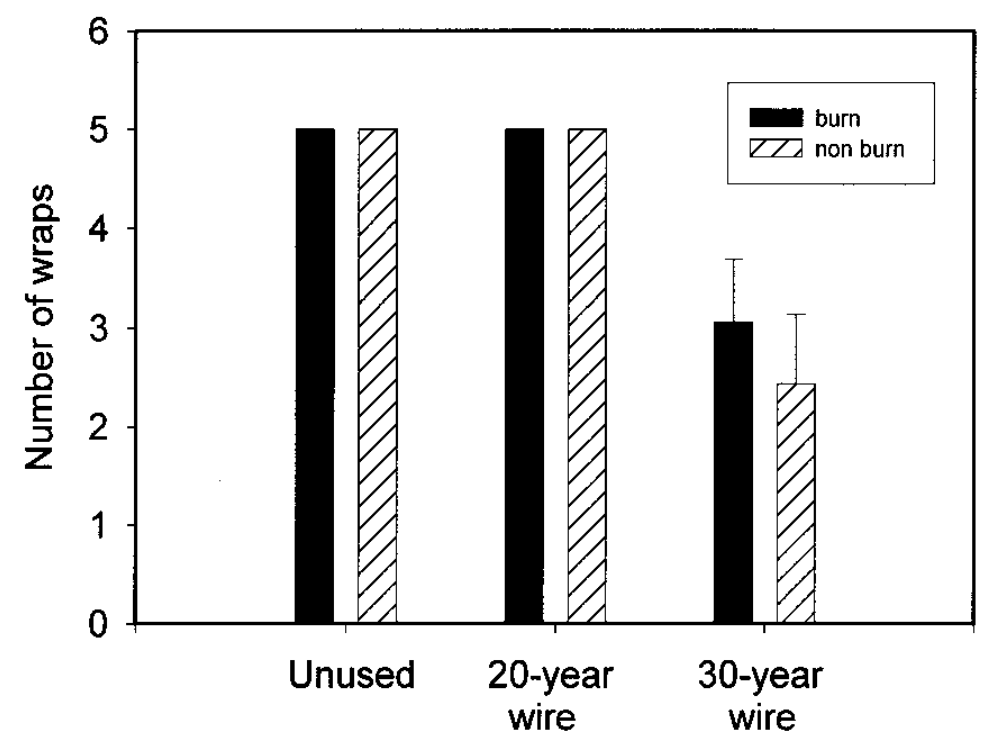

Fig. 3. Number of wraps before failure of single strands of barbed wire subjected to grassland fire. Values are means of 9 observations each for burn and non burn; bars are 1 standard error. Five turns indicates no failure. Burn treatments did not differ $(P>0.05)$ for wire of any age.

corroded wire is brittle and weak, so that when the wire breaks for any reason, repair is difficult. We conclude that the problems managers experience when repairing breaks in old wire subjected to grassland fire are not a result of fire, but rather brittle and weak wire resulting from exposure to the corrosive elements of the environment.

\section{Literature Cited}

ASTM. 1995. Annual book of ASTM standards. Section 1. Iron and Steel Products. Volume 01.06. Coated steel products. ASTM. Philadelphia, Penn.

Bidwell, T.G. and D.M. Engle. 1991. Behavior of headfires and backfires on tallgrass prairie, pp. 344-350. In: S. C. Nodvin and T. A. Waldrop (eds.), Fire and the environment: ecological and cultural perspectives: Proceedings of an international symposium. Gen. Tech. Rep. SE-69. USDA. For. Serv, Southeast. For. Exp. Sta., Asheville, N.C.

Bidwell, T.G. and D.M. Engle. 1992. Relationship of fire behavior to tallgrass prairie herbage production. J. Range Manage. 45:579-584.

Engle, D.M., T.G. Bidwell, A.L. Ewing, and J.R. Williams. 1989. A technique for quantifying fire behavior in grassland fire ecology studies. Southwest. Natur. 34:79-84.

Engle, D.M., T.G. Bidwell, J.F. Stritzke, and D. Rollins. 1990. Atrazine and burning in tallgrass prairie infested with prairie threeawn. J. Range Manage. 43:424-427.

Engle, D.M., J.R. Weir, D.L. Gay, and B.P. Dugan. 1998. Grassland fire effects on barbed wire. J. Range Manage. 51:621-624.

Engle, D.M., J.F. Stritzke, T.G. Bidwell, and P.L. Claypool. 1993. Late-summer fire and follow-up herbicide treatments in tallgrass prairie. J. Range Manage. 46:542-547.

Evans, P.D., P. Beutel, R.B. Cunningham, and C.F. Donnelly. 1994. Fire resistance of preservative-treated slash pine fence posts. Forest Products J. 44:37-39.

Kelly, V.I. 1975. Atmospheric corrosion investigation of aluminum-clad, zinc-coated, and copper-bearing steel wire and wire products (a twelve year report). ASTM Special Tech. Publ. 585. ASTM. Philadelphia, Penn.

McCarthy, D.F., W.G. Seaman, E.W.B. Da Costa, and L.D. Bezemer. 1972. Development and evaluation of a leach resistant fire retardant preservative for pine fence posts. J. Inst. Wood Sci. 6:24-31.

Reinhart, F.M. 1961. Twenty-year atmospheric corrosion investigation of zinc-coated and uncoated wire and wire products. ASTM Special Tech. Publ. No. 290. ASTM. Philadelphia, Penn. 